Original Research Paper

\title{
Diversifikasi Produk Olahan Buah Mangrove Dau (Bruguiera Gymnoorhiza) Untuk Cake Gulmerda Dan Sirup Dau di Desa Maitara Utara Kota Tidore Kepulauan
}

\author{
Rina $^{1}$, Salim Abubakar ${ }^{*}$, Masykhur Abdul Kadir'1, Adi Noman Susanto1, Ariyati H. Fadel', \\ Fajria Dewi Salim¹, Mesrawaty Sabar' ${ }^{1}$, Riyadi Subur ${ }^{1}$, Sri Endah Widiyanti ${ }^{1}$ \\ ${ }^{1}$ Program Studi Manajemen Sumberdaya Perairan Fakultas Perikanan dan Kelautan Universitas Khairun Ternate, \\ Ternate, Indonesia.
}

https://doi.org/10.29303/jpmpi.v3i2.1010

Sitasi: Abubakar, S., Abdul, K. M, Serosero, R. H, Subur. R, Widiyanti. S.E, Susanto. A. N \& Rina. (2021). Pemanfaatan Limbah Cangkang Kerang Untuk Produk Kerajinan Tangan Masyarakat Pesisir. Jurnal Pengabdian Magister Pendidikan IPA, 4(4)

\section{Article history}

Received: 15 September 2021

Revised: 20 September 2021

Accepted: 27 September 2021

*Corresponding Author: Salim

Abubakar, Program Studi Budidaya Perairan Fakultas Perikanan dan Kelautan Universitas Khairun Ternate, Ternate, Indonesia. Email: mylasrinaldy@gmail.com

\begin{abstract}
Mangrove forests are biological resources found in coastal areas that have ecological and economic functions. Bruguiera gymnorrhiza is a type of mangrove that grows in the middle and back zones with a muddy sand substrate. The fruit can be used as a local food source, especially in coastal areas that have the potential of mangrove forests, but of course must pay attention to the sustainability of the mangrove ecosystem. This PKM aims to apply the technology of processing the Bruguiera gymnorrhiza mangrove fruit for gulmerda cake and syrup which has a high selling value. The methods used in the Community Partnership Program (PKM) activities are lectures, practice, hedonic testing and mentoring. The results of PKM have increased public knowledge in utilizing raw materials that are around their environment to be processed into products that have a selling value, motivating people to be more independent and confident in developing businesses to improve community welfare, organoleptic testing, Cake gulmerda products are products that have higher score. The formation of the entrepreneurial group "Let's Feel Creative" in the context of the sustainability of training activities.
\end{abstract}

Keywords: Diversification, processed mangrove fruit, gulmerda cake, Dau syrup, North Maitara

\section{Pendahuluan}

$\begin{array}{cccc}\text { Pemanfaatan potensi } & \text { sumberdaya } & \text { hasil } \\ \text { perikanan khususnya } & \text { hasil } & \text { laut }\end{array}$ belum banyak termanfaatkan secara optimal dimasyarakat. Salah satu potensi sumberdaya hasil perikanan yang belum termanfatkan secara optimal salah satunya adalah mangrove. Hutan mangrove merupakan sumberdaya hayati yang terdapat di wilayah pesisir yang memiliki fungsi ekologis dan ekonomis. Fungsi ekologis sebagai peredam gelombang dan angin badai, pelindung pantai dan abrasi, sebagai daerah asuhan (nursery ground), daerah mencari makan (feeding ground), dan daerah pemijahan (spawning dround) bermacammacam biota perairan (ikan, udang dan kerangkerangan). Secara ekonomis sebagai kayu bakar, arang, bangunan, alat tangkap, chips dan bahan makanan (Rajis et al., 2017; Efriyeldi et al., 2019).

Salah satu fungsi hutan mangrove yang masih sedikit sekali diketahui oleh masyarakat umum adalah sumberdaya mangrove sebagai salah satu bahan baku makanan alternatif. Buah mangrove memiliki prospek sangat baik untuk dikembangkan menjadi bahan pangan alternatif berbagai macam resep makan, terutama bagi 
masyarakat di sekitar pesisir pantai, juga sebagai penyedia karbohidrat maupun sebagai bahan baku industri (Sahil dan Soamole, 2013). Pemanfaatan buah mangrove semakin banyak produknya dan salah satu pemanfaatan buah mangrove adalah sebagai tepung bahan baku pembuatan kue seperti roti, cake, sirup, selai, juice, donat, onde-onde, dodol, permen dan teh (Priyono et al., 2010; Djajati dan Rosida, 2015; Sugianto, 2019).

Bruguiera gymnorrhiza merupakan salah satu jenis mangrove yang tumbuh pada zona tengah dan zona belakang dengan jenis subtrsat pasir berlumpur. Buahnya dapat dimanfaatkan sebagai sumber pangan lokal terutama di wilayah pesisir yang memiliki potensi hutan mangrove, namun tentunya harus memperhatikan keberlanjutan dari ekosistem mangrove (Mulyatum, 2018).

Pulau Maitara Kota Tidore Kepulauan memiliki potensi hutan mangrove yang tersebar di pesisir pantainya, namun umumnya pemanfaatan hutan mangrove hanya terfokus pada kayu bakar, obat-obatan serta konversi lahan menjadi lahan pemukiman dan jalan raya, sehingga sebagian areal hutan mangrove sebagian habitat mengalami kerusakan. Padahal mangrove memiliki prospek sangat baik untuk dikembangkan menjadi bahan pangan alternatif berbagai penyedia karbohidrat dan aneka bahan makanan dan minuman serta bahan baku industri rumah tangga.

Pemerintah Desa Maitara Utara telah berupaya melakukan kegiatan pemberdayaan masyarakat dengan membentuk kelompok usaha wanita melalui kegiatan Pemberdayaan dan Kesejahteraan Keluarga (PKK) guna meningkatkan aktifitas dan kreatifitas masyarakat. Akan tetapi pada kenyataannya masih belum optimal karena aktifitas kelompok wanita PKK masih terbatas pada kegiatan ketika ada kunjungan pemerintah Kota Tidore Kepulauan, tetapi kegiatan pemanfaatan buah mangrove sebagai produk bahan makanan belum pernah dilakukan. Kurangnya informasi dan rendahnya penguasaan ilmu pengetahuan dan teknologi di bidang pengelolaan mangrove merupakan salah satu kendala utama dalam pemanfaatn olahan buah mangrove di Pulau Maitara, sehingga masyarakat khususnya kelompok wanita belum memanfaatakan tanaman tersebut secara maksimal. Dengan penerapan ilmu pengetahuan dan teknologi produk olahan mangrove diharapkan dapat meningkatkan keterampilan dan penguasaan teknologi dalam upaya peningkatkan kesejahteraan hidup masyarakat.

Permasalahan utama yang dihadapi oleh kelompok masyarakat khususnya kelompok wanita PKK adalah kurangnya pengetahuan anggota dalam memanfaatkan bahan baku lokal yaitu mangrove yang menjadi potensi daerah tersebut, masih tebatasnya ketersediaan peralatan pengolahan dan pengemasan. Masih minimnya pengetahuan kelompok mengenai teknik pengolahan yang tepat untuk memperolah mutu produk yang baik serta masih kurangnya pengetahuan masyarakat tentang difersivikasi produk berbahan baku buah mangrove. Hal ini yang menyebabkan kelompok belum mampu berinovasi dalam memanfaatkan potensi pangan lokal yang ada khususnya buah mangrove. PKM ini bertujuan menerapkan teknologi olahan buah mangrove Bruguiera gymnorrhiza untuk cake gulmerda dan sirup yang memiliki nilai jual yang tinggi.

\section{Metode}

\section{Tempat dan Waktu}

Pelaksanaan pengabdian olahan buah mangrove sebagai bahan makanan dilaksanakan di Desa Maitara Utara Kecamatan Tidore Utara. Sedangkan waktu pelaksanaan selama selama 7 bulan yaitu April - Oktober 2021.

\section{Metode Pendekatan}

Metoda yang digunakan dalam kegiatan Program Kemitraan Masyarakat (PKM) yaitu :

a) Metode ceramah yaitu pemberian teori dasar dalam pengolahan produk pangan berbahan baku mangrove menjadi produk yang tahan lama, aman, bernilai gizi tinggi dan dapat diterima masyarakat secara luas serta mempunyai nilai tambah secara ekonomi.

b) Metode praktek yaitu memberikan pelatihan yang ditekankan pada kemampuan ketrampilan masyarakat dalam pengolahan aneka produk dari mangrove

c) Metode pengujian hedonic yaitu menggunakan uji organoleptik untuk mengetahui tingkat kesukaan atau kelayakan suatu produk agar dapat diterima oleh konsumen. 
d) Metode pendampingan untuk keberlanjutan kegiatan usaha dan pemasaran hasil.

\section{Pelaksanaan Kegiatan}

Pelaksanaan kegiatan di awali dengan pembentukan kelompok yang dijadikan mitra sebanyak 2 kelompok, dimana masing-masing kelompok terdiri dari 5 orang. Langkah-langkah pelaksanaan kegiatan adalah proses pendampingan yang akan dilakukan dalam menyelesaikan permasalahan yang dihadapi oleh kelompok mitra tentang difersivikasi dan pengembangan produk olahan buah mangrove yang dimulai dari pemilihan jenis mangrove, proses pembuatan tepung, olahan produk dan pengemasan. Jenis mangrove yang dijadikan produk olahan cake gulmerda dan sirup yaitu jenis Bruguiera gymnorrhiza yang dalam bahasa lokal Desa Maitara disebut dengan Dau.

Adapun uraian kegiatan yang akan dilaksanakan disajikan pada Tabel 1 .

Tabel 1. Uraian pelaksanaan kegiatan

\begin{tabular}{|c|c|c|}
\hline No. & Uraian Kegiatan & Program \\
\hline 1. & $\begin{array}{l}\text { Penyuluhan, } \\
\text { sosialisasi }\end{array}$ & $\begin{array}{ll}\text { Diversifikasi } & \text { dan } \\
\text { pengembangan } & \\
\text { produk olahan buah } \\
\text { mangrove }\end{array}$ \\
\hline 2. & $\begin{array}{l}\text { Pembuatan produk } \\
\text { olahan } \\
\text { a. Pemilihan } \\
\text { bahan baku. } \\
\text { b. Pembuatan } \\
\text { tepung } \\
\text { c. Membuat } \\
\text { formulasi } \\
\text { produk } \\
\text { d. Cara } \\
\text { penanganan dan } \\
\text { pengolahan } \\
\text { bahan baku } \\
\text { menjadi produk } \\
\text { hasil olahan. } \\
\text { Pengemasan } \\
\text { dan } \\
\text { penyimpanan } \\
\text { produk }\end{array}$ & $\begin{array}{l}\text { Pemilihan bahan baku } \\
\text { (jenis mangrove) } \\
\text { Metode pembuatan } \\
\text { tepung } \\
\text { Tahap formulasi } \\
\text { Pengolahan/produksi }\end{array}$ \\
\hline 3 & $\begin{array}{l}\text { Pengujian mutu } \\
\text { produk }\end{array}$ & $\begin{array}{l}\text { Analisa mutu produk } \\
\text { (organoleptik) }\end{array}$ \\
\hline
\end{tabular}

\section{Hasil dan Pembahasan}

\section{Sosialisasi Program}

Sosialisasi Program Kemitraan Masyarakat (PKM) Mandiri bertujuan untuk memberitahukan rencana program pelatihan proses olahan buah mangrove yang hendak dilakukan kepada masyarakat Desa Maitara Utara Kecamatan Tidore Utara Kota Tidore Kepulauan. Dalam sosialisasi inti dilakukan dalam dua tahap yaitu :

1. Kepala Kelurahan beserta jajaranya dengan tujuan menyampaikan secara umum metode pelatihan yang akan dilakukan melalui Program Kemitraan Masyarakat (PKM) Mandiri. Dari sosialisasi ini diperoleh 10 orang yang berminat mengikuti pelatihan olahan buah mangrove dan semuanya masuk dalam kepengurusan PKK.

2. Dilakukan secara langsung kepada 10 orang yang berminat mengikuti pelatihan olahan buah mangrove. Sosialisasi ini bertujuan memberitahukan bentuk kegiatan yang akan dilaksanakan berupa penyuluhan, pemilihan jenis mangrove, pembuatan tepung, olahan aneka produk, pengemasan, dan pembentukan kelompok usaha.

\section{Pembekalan Pengetahuan Dasar Olahan Buah Mangrove}

Pembekalan pengetahuan dasar olahan buah mangrove bertujuan untuk menambah pengetahuan kepada peserta pelatihan sebagai bekal dalam melakukan olahan buah mangrove sebagai bahan makanan. Dari kegiatan ini, diharapkan peserta pelatihan memiliki pengetahuan dasar dan menambah antusiasme dalam pembuatan aneka olahan buah mangrove sebagai salah satu sumber penghasilan tambahan.Kegiatan ini dilakukan dalam bentuk penyajian materi (presentasi) dan diskusi.

Materi yang disajikan berupa 1) Penyuluhan tentang buah mangrove manfaatnya bagi lingkungan dan manfaat tambahan yang dapat diperoleh dari buah mangrove; 2) persiapan dan penanganan awal bahan baku mangrove, dan teknik pengolahannya menjadi produk olahan yang memiliki nilai ekonomis, serta pengemasan; 3) analisis organoleptik adalah uji hedonik (kesukaan) merupakan salah satu uji penerimaan konsumen terhadap suatu produk baru.

Dalam pelaksanaan penyuluhan, diperoleh umumnya masyarakat belum mengetahui bahwa fungsi hutan mangrove selain sebagai pelindung pantai juga potensial dimanfaatkan sebagai bahan 
baku produk olahan yang bernila jual. Kegiatan selanjutnya berupa demonstrasi pembuatan produk olahan menggunakan jenis mangrove Bruguiera gymnorrhiza yang ada di hutan mangrove Pulau Maitara. Kegiatan demo yang dilakukan adalah pembuatan cake golmerlda dan sirup dau. Pembekalan pengetahuan dasar olahan buah mangrove disajikan pada Gambar 1 .

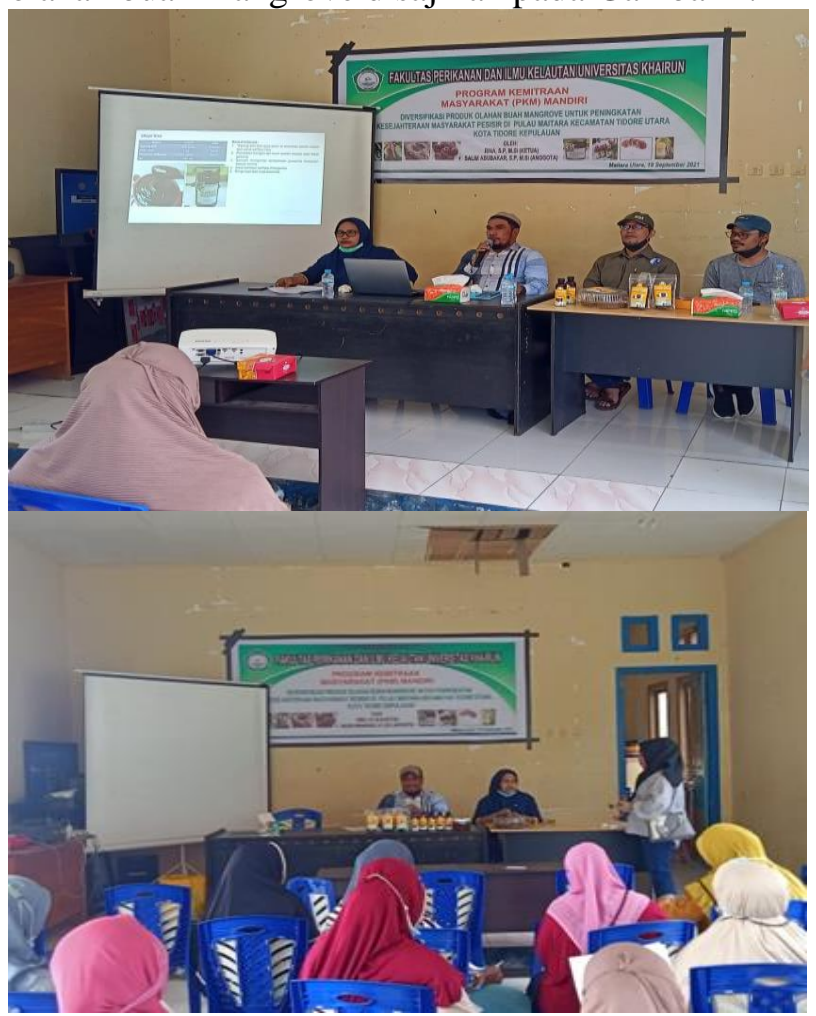

Gambar 1. Pembekalan pengetahuan dasar olahan buah mangrove

\section{Proses Pembuatan Tepung Buah Bruguiera gymnorrhiza}

Umumnya bahan baku pembuatan aneka olahan buah mangrove diawali dengan proses pembuatan tepung dari buah mangrove. Proses pembuatan tepung dapat dlihat pada gambar 2 . Dalam proses pembuatan tepung, buah mangrove segar yang diambil dari pohon selanjutnya di cuci bersih dan direbus selama 4 jam. Setelah itu dikupas dan di potong kecil-kecil. Potongan buah mangrove selanjutnya di rendam dan ditambahkan arang batok kelapa dan dgani airnya setiap hari. Pekerjaan ini dilakukan sampai air rendaman berwarna putih bersih dan terasa tawar. Ini mengindikasikan bahwa tannin dalam buah mangrove sudah tidak ada.
Menurut Hagerman (2002), tanin bukan merupakan zat gizi namun dalam jumlah kecil dapat bermanfaat bagi kesehatan. Frazier et al. (2010) menyatakan bahwa tanin termasuk dalam kelompok polifenol yang berpotensi sebagai antioksidan dan berpengaruh terhadap kesehatan manusia. Senyawa ini menimbulkan rasa sepat dalam buah, tetapi mempunyai fungsi memperlancar sistem pencernaan. Sirkulasinya dalam darah berguna untuk menyerang virus (Wirakusumah, 1998).

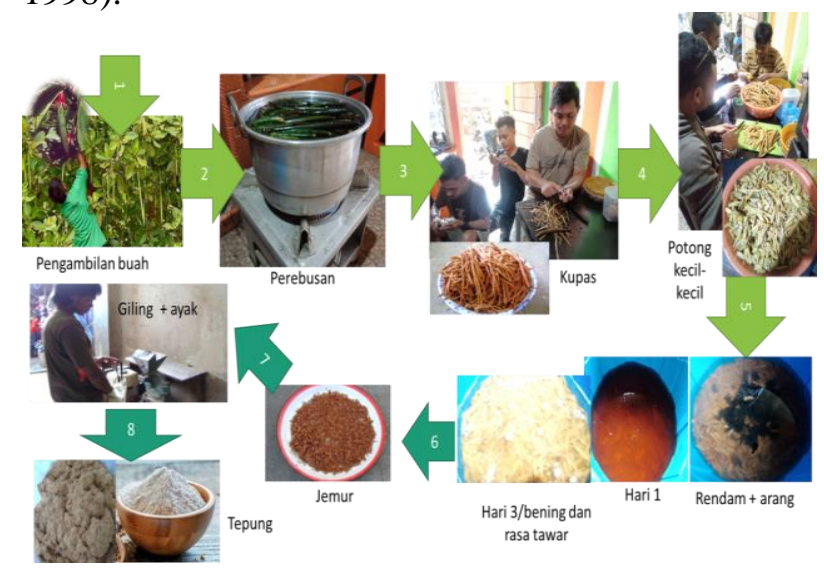

\section{Olahan Cake Gulmerda}

Alat dan bahan yang digunakan dalam pembuatan Cake Gulmerda disajikan pada tabel 2. Sedangkan hasil olahannya disajikan pada Gambar 3.

Tabel 2. Alat dan bahan yang digunakan dalam olahan Cake Gulmerda

\begin{tabular}{|c|c|c|}
\hline Bahan & Jumlah & Alat \\
\hline Tepung dau & 100 gram & Mixer \\
\hline Gula pasir & $\begin{array}{ll} & 180 \\
\text { gram } & \end{array}$ & $\begin{array}{c}\text { Baskom } \\
\text { Oven }\end{array}$ \\
\hline Telur & 6 butir & Kompor \\
\hline Gula merah & 50 gram & Loyang \\
\hline Vanili & Secukupnya & Spatula \\
\hline $\begin{array}{l}\text { SP (Pengembang } \\
\text { kue) }\end{array}$ & $1 / 2 \mathrm{st}$ & \\
\hline Bumbu Spekoek & $1 \mathrm{st}$ & \\
\hline SKM Putih & 1 sachet/ $2 \mathrm{sm}$ & \\
\hline Kenari & Secukupnya & \\
\hline $\begin{array}{l}\text { Margarin } \\
\text { (Cairkan) }\end{array}$ & 70 gram & \\
\hline
\end{tabular}


Cara membuat :

1. Kocok telur, gula pasir dan SP sampai mengembang, selanjutnya masukkan gula merah dan bumbu spekoek dan kocok lagi sampai kental.

2. Masukkan tepung dau ke dalam kocokan telur, aduk rata.

3. Terakhir tambahkan vanili, SKM dan margarin cair aduk dg metode balik sampai tercampur dan tidak ada margarin mengendap di dasaar adonan.

4. Oles loyang dg margarin, lalu masukan adonan kue sampai habis, hentakkan loyang agar udara yg ada di adonan keluar.

5. Panggang kue selama \pm 45 menit sampai matang.

6. Setelah matang angkat tunggu agak dingin keluarkan dr cetakan.

7. Panaskan coklat batang dengan suhu api yang rendah sambil terus di aduk sampai coklat perlahan mencair. Jika coklat sudah mencair, ratakan coklat yang sudah cair tersebut pada cake dan taburi kenari di atasnya.

8. Setelah dingin

9. Cake siap disajikan

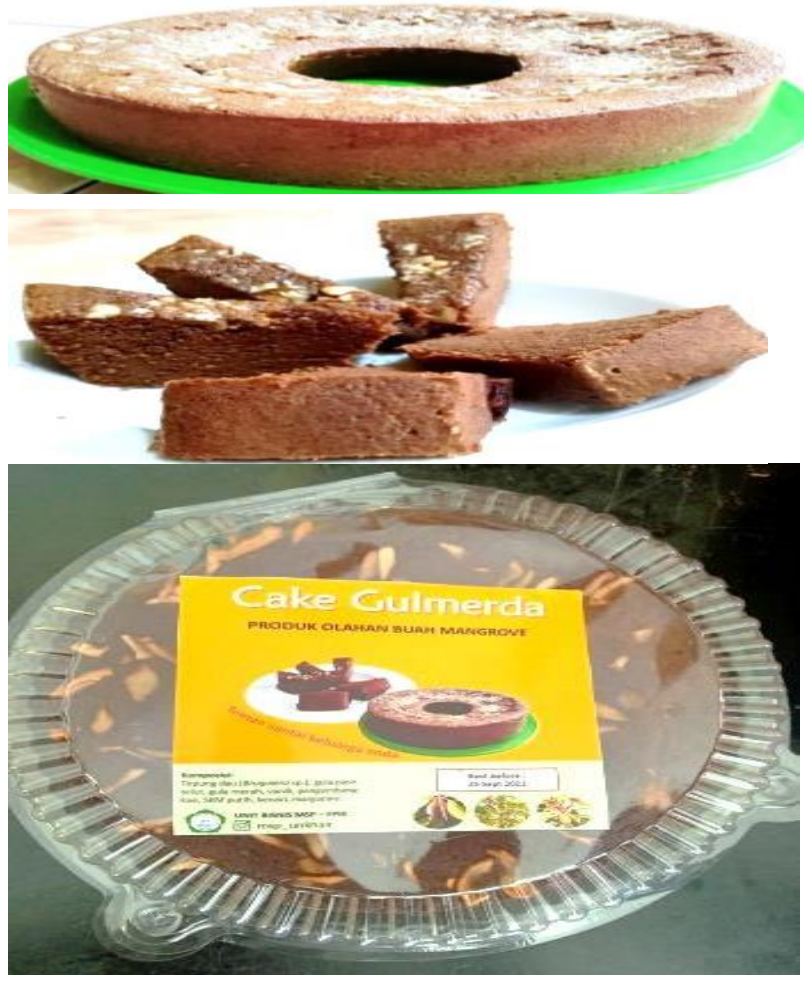

Gambar 3. Cake Gulmerda

\section{Olahan Sirup Dau}

Alat dan bahan yang digunakan dalam pembuatan sirup dau dau disajikan pada tabel 3. Sedangkan hasil olahannya disajikan pada Gambar 4.

Tabel 3. Alat dan bahan yang digunakan dalam olahan Sirup Dau

\begin{tabular}{|l|c|c|}
\hline \multicolumn{1}{|c|}{ Bahan } & Jumlah & Alat \\
\hline Tepung dau & 50 gram & \multirow{2}{*}{$\begin{array}{c}\text { Kompor } \\
\text { Panci } \\
\text { Botol }\end{array}$} \\
\cline { 1 - 2 } Gula pasir & Kg & \\
\cline { 1 - 2 } $\begin{array}{l}\text { Pewarna } \\
\text { (merah/hijau/kuning) }\end{array}$ & 8 tetes & \\
\hline Eesens Frambozen & $1 \mathrm{sm}$ & \\
\hline Daun pandan & 3 lembar & \\
\hline Air & $500 \mathrm{ml}$ & \\
\hline
\end{tabular}

\section{Cara membuat :}

1. Rebus gula pasir, tepung dau dan daun pandan dengan air sebanyak $500 \mathrm{ml}$ sampai mendidih, lalu matikan api.

2. Tunggu sampai suhu air rebusan turun, kemudian tambahkan esens frambozen dan pewarna makanan.

3. Aduk rata sirup, kemudian tuang ke dalam botol bersih yang memiliki tutup rapat.

4. Simpan di dalam lemari es.

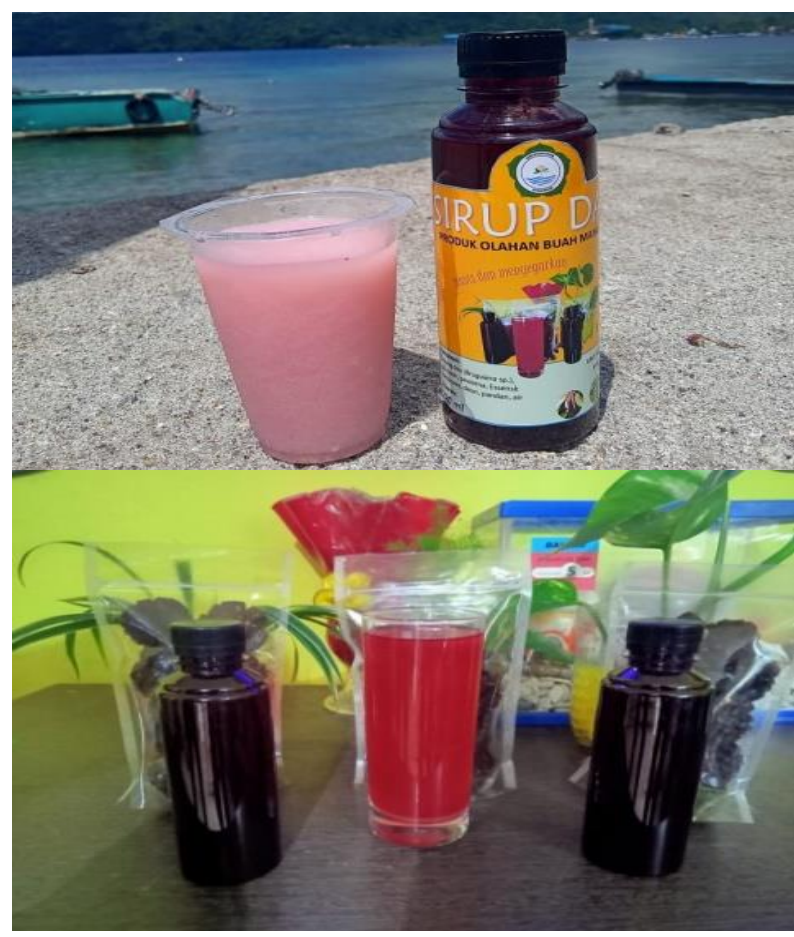

Gambar 4. Sirup dau 
Melalui pelatihan dan bimbingan intensif dalam setiap tahapan proses olahan produk buah Bruguiera gymnorrhiza, dianggap berhasil karena semua produk yang diajarkan dapat dilakukan dengan baik. Peserta pelatihan begitu bersemangat dan antusiasme dalam menekuni pelatihan olahan buah mangrove sebagai makanan, ketika mendapatkan kendala dalam pembuatan produk langsung ditanyakan dan diskusikan bersama dalam kelompok. Dengan semangat dan antusiasme itu merupakan modal mental dalam pengembangan berbagai produk olahan buah mangrove di masa mendatang. Hasil aneka produk olahan yang telah dibuat, selanjutnya dipresentasikan oleh masing-masing ketua kelompok dengan menyampaikan kekurangan, kelebihan, tingkat kesulitan dan kemudahan dalam pembuatan produk serta pesan dan kesan diadakan pelatihan.

Kegiatan demonstrasi tersebut telah membuka wawasan peserta dalam memanfaatkan bahan baku yang ada disekitar lingkunga mereka untuk diolah menjadi produk yang memiliki nilai jual. Selain itu kegiatan tersebut mampu meningkatkan rasa percaya diri peserta dalam membuat produk olahan dengan menggunakan bahan baku lokal. Kegiatan pengabdian yang telah dilakukan menjadi awal dari terciptanya kelompok usaha-usaha kecil yang dapat memberdayakan masyarakat dan diharapkan dapat meningkatkan pendapatan masyarakat.

\section{Analisis Uji Organoleptik}

Uji organoleptik atau uji Hedonik adalah pengujian yang dilakukan dengan menggunakan indera manusia sebagai alat utama dalam mengukur daya penerimaan terhadap produk atau pernyataan kesan tentang baik atau buruknya mutu suatu produk. Metode ini dilakukan setelah semua olahan sudah menjadi produk (Setyaningsih et al., 2010).

Peserta pelatihan diminta untuk mengungkapkan tanggapannya tentang kesukaan atau ketidaksukaan dengan menggunakan skala penilaian 1 (sangat tidak suka), 2 (tidak suka), 3 (kurang suka), 4 (suka), dan 5 (sangat suka) terhadap produk olahan buah mangrove Dau (Bruguiera gymnorrhiza). Uji organoleptik meliputi rangking mutu rasa, warna, aroma, dan tekstur. Para peserta diminta memberikan penilaian terhadap warna dengan cara dilihat, aroma dengan cara dicium dan rasa serta tekstur dengan cara mencicipinya. Hasil analisis organoleptik produk olahan buah Dau disajikan pada Tabel 4.

Tabel 4. Uji organoleptik produk olahan buah Dau

\begin{tabular}{ccccc}
\hline \multirow{2}{*}{ Produk } & \multicolumn{4}{c}{ Penilaian } \\
\cline { 2 - 5 } & Rasa & Warna & Aroma & Tekstur \\
\hline Cake gulmerda & 4.90 & 4.95 & 4.90 & 4.71 \\
Sirup dau & 4.57 & 4.76 & 4.62 & 4.76 \\
\hline \multicolumn{2}{c}{ Berdasarkan } & Tabel 4 & diperoleh & Cake
\end{tabular}

gulmerda memiliki nilai skoring mutu untuk rasa, warna dan aroma lebih tinggi sedangkan mutu tekstur lebih tinggi sirup dau. Hal tersebut menunjukkan responden lebih menyukai cake gulmerda karena memiliki rasa manis dari gula merah, warna menarik (kecoklatan) dan aroma wangi. Rasa merupakan faktor utama yang menyebabkan suatu produk pangan dapat disukai atau tidak oleh konsumen. Rasa menjadi faktor yang sangat menentukan pada keputusan akhir konsumen untuk menolak atau menerima suatu makanan.

Rasa yang ditimbulkan oleh produk pangan dapat berasal dari bahan pangan itu sendiri juga berasal dari zatzat yang ditambahkan dari luar saat proses berlangsung, sehingga dapat menimbulkan rasa yang tajam atau sebaliknya jadi berkurang. Rasa dipengaruhi oleh beberapa faktor yaitu senyawa kimia, suhu, konsetrasi dan interaksi dengan komponen rasa yang lain (Mayasari, 2015; Winarno, 1996).

Penambahan gula merah lebih banyak dibandingkan dengan gula pasir menambah cita rasa terhadap cake gulmerda sehingga terasa lebih gurih dan enak rasanya. Menurut Wintah et al (2018), bahwa rasa adalah sifat organoleptik terpenting pada suatu produk. Rasa pada suatu produk dapat dipengaruhi oleh gula. Selain itu rasa tannin dari Bruguiera gymnorrhiza hilang karena saat proses pembuatan tepung rasa tannin sudah berkurang bahkan dianggap sudah hilang sehingga tidak ada rasa sepat (pahit/asam) dari tepung. Winarno (1996) adanya tanin dalam makanan juga dapat menentukan cita rasa bahan makanan tersebut.

Warna cake gulmerda dipengaruhi oleh tepung buah mangrove berwarna coklat putih dan tidak menggunaan pewarna makanan, sehingga warna yang dihasilkan merupakan warna alami dari 
tepung buah mangrove. Sedangkan sirup dau ditambahkan pewarna makanan. Secara alami buah lindur memberikan warna kecoklatan. Bisa dibentuk menjadi adonan yang kalis dan mempunyai kandungan amilosa hampir sama dengan beras yaitu sekitar 17\% (Kardiman et al., 2017).

Penyebab suatu bahan makanan berwarna adalah salah satunya karena adanya pigmen yang dikandung oleh bahan makanan tersebut. Warna pigmen buah umumnya putih kecokelatatan begitu juga dengan buah mangrove mengandung pigmen buah berwarna putih kecokelatan (Wintah et al., 2018).

Aroma menjadi daya tarik dalam pengolahan produk makanan. Aroma yang disebarkan oleh makanan merupakan daya tarik yang sangat kuat dan mampu merangsang indera penciuman penerima sehingga membangkitkan selera. Tingginya nilai skoring pada produk Cake Gulmerda karena adanya pencampuran berbagai macam bahan terutama gula merah sehingga aroma dari bahan alami dari tepung tertutupi, sedangkan produk sirup dau hanya menggunakan pewarna makanan dan gula pasir sehingga aroma asli dari tepung masih ada. Ini mengindikasikan bahwa dalam pembuatan produk olahan buah mangrove harus ada tambahan bahan lainnya yang dapat menghilangkan aroma asli dari buah mangrove.

Setiap orang mempunyai perbedaan kemampuan indera penciuman, meskipun mereka dapat membedakan aroma namun setiap orang mempunyai kesukaan yang berbeda. Responden memberi penilaian berdasarkan kuat tidaknya aroma wangi yang terdapat dalam semua produk olahan buah mangrove Bruguiera gymnorrhiza. Aroma yang kuat pada produk olahan buah mangrove sangat penting karena dapat meningkatkan minat wisatawan dalam membeli produk biskuit tersebut. Aroma adalah bau yang sukar diukur sehingga menimbulkan pendapatyang berlainan dalam menilai kualitas (Sitorus, 2019).

Tingginya skoring mutu tekstur pada sirup dau karena produk ini merupakan produk minuman yang pada saat proses pembuatannya dicampur dengan tepung buah dan gula pasir, sehingga tekstur yang dirasakan sangat halus. Ini mengindikasikan dalam pembuatan olahan produk berbahan baku tepung buah mangrove harus dicampur dengan sedikit tepung berbahan lain. Sebagaimana hasil penelitian Wintah et al (2018) dengan menggunakan jenis mangrove Sonneratia alba. Buah mangrove pedada memiliki tekstur yang berserat, sehingga semakin tinggi konsentrasi penambahan buah mangrove pedada pada pembuatan cokelat mangrove maka semakin tidak disukai oleh panelis. Tekstur digunakan untuk menyatakan bentuk fisik produk. Tekstur juga berpengaruh terhadap daya tarik terhadap seseorang. Salah satu cara penentuan tekstur suatu bahan adalah dengan memberikan beban terhadap bahan misalnya dengan pemeriksaan bekas jari.

Buah Bruguiera gymnorrhiza cocok untuk dieksplorasi sebagai sumber pangan lokal baru karena mengandung karbohidrat yang sangat tinggi, yaitu $85.1 \mathrm{~g} / 100 \mathrm{~g}$ bahan. Kandungan gizi yang terdapat dalam buah lindur cukup lengkap sehingga dapat diolah menjadi kue, cake, dicampur dengan nasi atau dimakan langsung dengan bumbu kelapa. Buah lindur cocok untuk diolah menjadi tepung karena kandungan karbohidrat yang tinggi. Proses pembuatan kue salju dari tambahan tepung lindur menunjukkan bahwa rasa dan tekstur berkategori baik, artinya tepung buah lindur dapat diolah menjadi kue kering putri salju (Kardiman et al., 2017).

\section{Pembentukan Kelompok Wirausaha}

Dalam rangka keberlanjutan kegiatan pelatihan, maka dibentuk kelompok wirausah yang berguna sebagai wadah dalam meningkatkan keterampilan dan kreativitas kelompok. Desa Maitara Utara merupakan desa wisata pantai, sehingga dengan terbentuknya kelompok wirausaha diharapkan dapat menambah bentuk pola usaha dalam areal wisata, sehingga berbagai bentuk pelayanan wisata dapat terwujud, seperti ketersediaan kuliner dan berbagi macam souvenir/cendaramata yang dapat disedikan oleh pengelola wisata baik yang berasal dari laut maupun dari daratan. Pembentukan kelompok perajin sangat penting untuk pengembangan seni kerajinan, karena dengan adanya kelompok akan mampu meningkatkan kapasitas produksi dan melayani permintaan konsumen yang lebih besar (Muhammad et al., 2020).

Pembentukan kelompok perajin dilakukan setelah selesainya kegiatan pelatihan. Berdasarkan musyawarah dari semua peserta dan Kepala 
Kelurahan maka diperoleh kelompok perajin dengan nama "Mari Rasa Kreatif". Semua peserta pelatihan bersedia masuk dalam struktur organisasi beranggotakan 10 orang. Pelaksanaan Program Kemitraan Masyarakat (PKM) mandiri dengan tema "Diversifikasi Produk Olahan Buah Mangrove Untuk Peningkatan Kesejahteraan Masyarakat Pesisir" merupakan pelatihan awal dalam upaya pengembangan olahan buah mangrove sebagai bahan makanan di wilayah Kota Tidore Kepulauan dan khususnya di Desa Maitara Utara, sehingga harus dilakukan pembinaan secara berkala terhadap kelompok wirausaha yang sudah terbentuk agar keberlanjutan program dapat berjalan dengan baik. Hal ini menjadi kesepakatan bersama antara kelompok yang terbentuk, pihak kelurahan dan pihak Program Studi Manajamen Sumberdaya Perairan Fakultas Perikanan dan Kelautan Universitas Khairun Ternate menjadikan kelompok "Mari Rasa Kreatif" sebagai kelompok binaan Fakultas Perikanan dan Kelautan. Kesepakatan ini dituangkan dalam Surat Keputusan Dekan FPK tentang Struktur organisasi kepengurusan. Adapun susunan struktur organisasi disajikan pada Gambar 5.

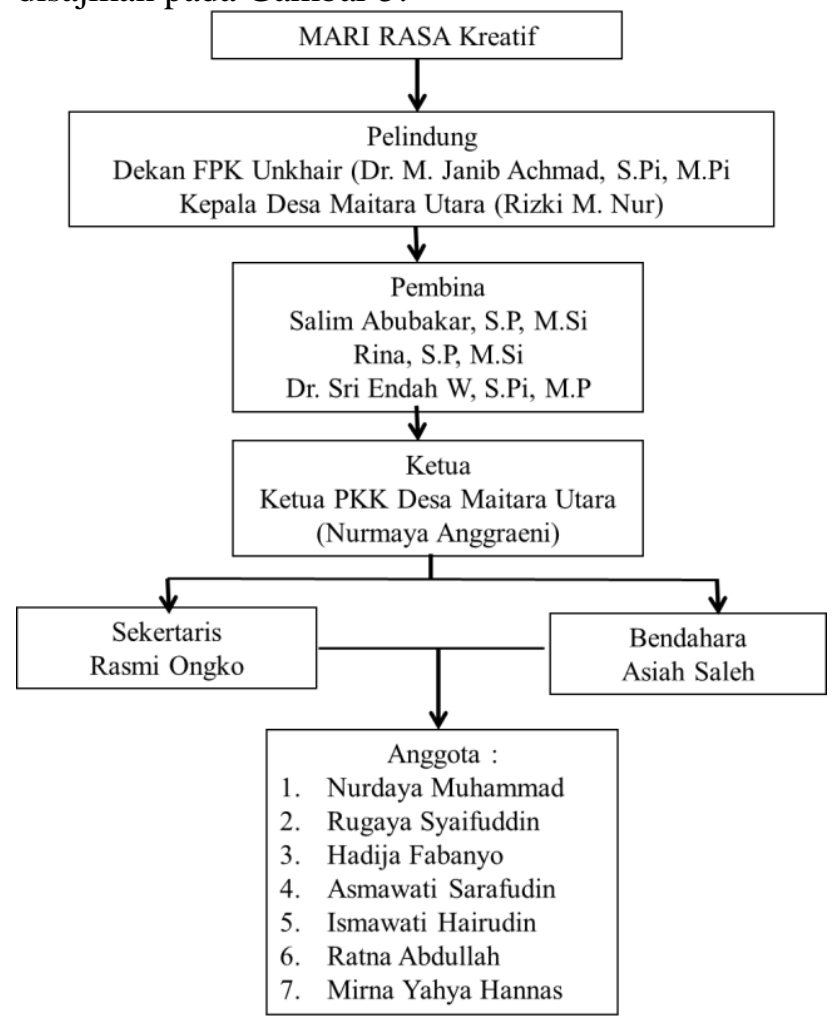

Gambar 6. Struktur Organisasi kelompok wirausaha "Mari Rasa Kreatif

\section{Kesimpulan}

Berdasarkan hasil PKM Mandiri yang telah dilakukan maka dapat dikemukakan beberapa kesimpulan sebagai berikut :

1. Kegiatan PKM Mandiri telah menambah pengetahuan masyarakat dalam memanfaatkan bahan baku yang ada disekitar lingkungan mereka untuk diolah menjadi produk yang memiliki nilai jual.

2. Kegiatan yang telah dilakukan mampu memotivasi masyarakat untuk lebih mandiri dan percaya diri dalam mengembangkan usaha guna meningkatkan kesejahteraan masyarakat.

3. Hasil uji organoleptik, semua produk disukai oleh responden dan produk Cake gulmerda merupakan produk yang memiliki nilai skoring lebih tinggi.

4. Kegiatan PKM mandiri ini telah mampu menciptakan kerjasama yang baik antara lembaga perguruan tinggi dengan masyarakat.

5. Terbentuknya kelompok wirausaha "Mari Rasa Kreatif" dalam rangka keberlanjutan kegiatan pelatihan.

\section{Ucapan Terima Kasih}

Terima kasih yang setinggi-tingginya penulis ucapkan kepada Fakultas Perikanan dan Kelautan Universitas Khairun atas dukungan dana yang telah diberikan melalui Skema Program Kemitraan Masyarakat dan juga kepada Kepala Desa Maitara Utara, Ketua Program Studi Manajemen Sumberdaya Perairan beserta para dosen MSP atas dukungannya serta menfasilitasi kami hingga PKM ini dapat terlaksana.

\section{Daftar Pustaka}

Djajati, S dan D. F. Rosida. 2015. Pengembangan Produk Olahan Mangrove dan Perikanan di Kawasan Pantai Wonorejo Surabaya. Prosiding Seminar Nasional "Sinergi Hasil Penelitian dan Pengabdian kepada Masyarakat untuk Menumbuhkan Kapasitas Inovasi di Bidang Teknologi, Pertanian, Sosial dan Ekonomi. Hal 381 - 387. 
Efriyeldi,., A. Mulyadi , J. Samiaji1, Nursyirwani, Elizal dan E. Suanto. 2019. Peningkatan Nilai Ekonomi Ekosistem Mangrove Melalui Pengolahan Buah Api-Api (Avicennia sp) Sebagai Bahan Makanan Di Desa Sungai Kayu Ara Kabupaten Siak. Journal of Rural and Urban Community Empowerment, 1 (1) : 1 - 8 .

Frazier RA, Deaville ER, Green RJ, Stringano E, Willoughby I, Plant J, and Mueller-Harvey I. 2010. Interaction of tea tannins and condensed tannins with proteins. $J$ of Pharm and Biomedic Analysis 51:490-495.

Hagerman AE. 2002. Tannin Chemistry. Departement Chemistry and Biochemistry.Oxford (USA): Miami University.

Kardiman., M. Ridhwan dan Armi. 2017. Buah Lindur (Bruguera gymnorrhyza) sebagai Makanan Masyarakat Aceh Kepulauan. Jurnal Serambi Saintia, V (2) : $51-55$.

Mayasari, R. 2015. Kajian Karakteristik Biskuit yang Mempengaruhi Perbandingan Tepung Ubi Jalar (Ipomea Batatas L.) dan Tepung Kacang Merah (Phaseolus Vulgaris L.). Skripsi. Universitas Pasudan. Bandung

Mohamad, I., I. Sudana dan Hasdiana. 2020. Pengembangan Seni Kerajinan Kerang Di Desa Modelomo Kecamatan Kabila Bone Kabupaten Bone Bolango. Laporan Akhir Program Pengabdian Kepada Masyarakat Fakultas Teknik Universitas Negeri Gorontalo. Gorontalo.

Mulyatun. 2018. Pemberdayaan Masyarakat Pesisir Berbasis Potensi Lokal; Alternatif Ketahanan Pangan Berupa Tepung Mangrove. Jurnal Dimas, 18 (2): $211-238$.

Proyono, A., D. Ilminingtyas, Mohsan, L. S. Yuliani dan T. L. Hakim. 2010. Beragam Produk OLahan Berbahan Dasar Mangrove.

Kesemat. Semarang.

Rajis, Desmelati dan T. Leksono. 2017. Pemanfaatan Buah Mangrove Pedada (Sonneratia caseolaris) sebagai Pembuatan Sirup terhadap Penerimaan Konsumen.
Jurnal Perikanan dan Kelautan, 22 (1): 5150.

Sahil, J dan I. Soamole. 2013. Pemanfaatan Buah Mangrove Sebagai Sumber Makanan Alternatif di Halmahera Barat, Maluku Utara. Jurnal Biogenesis, 1 (2) : 91-96.

Setyaningsih D, Apriyantono A, Sari, MP. 2010. Analisa Sensori Industri Pangan dan Agro. IPB Press. Bogor.

Sitorus, A. K. 2019. Analisis Produk Olahan Buah Bruguiera Sexangula Menjadi Biskuit Dan Potensi Pasar Di Desa Sei Nagalawan Kecamatan Perbaungan Kabupaten Serdang Bedagai. Skripsi. Departemen Manajemen Hutan Fakultas Kehutanan Universitas Sumatera Utara Medan.

Sugianto. 2019. Diversifikasi Produk Olahan Mangrove Bisa Meningkatkan Kesejahteraan Masyarakat Pesisir Indramayu. Jurnal Mangifera Edu, 3 (2): 133-139.

Winarno, F.G. 1996. Kimia Pangan dan Gizi. Gramedia Pustaka Utama. Jakarta.

Wintah., A P. Heriyanti dan Kiswanto. 2018. Kajian Nilai Gizi Dan Organoleptik Cokelat Mangrove Dari Buah Sonneratia alba. Jurnal Litbang Kota Pekalongan, 15 : $26-34$. 